\title{
Nursing Staff Readiness regarding Utilization of Six Sigma of Quality Management in Critical Care Units
}

\section{Anwaar Mahmoud Fathi ${ }^{1}$, Eman Abd ElAlim Etway ${ }^{\mathbf{2}}$ and Fawzia Farouk Kamel ${ }^{\mathbf{3}}$}

(1) B.SC. of Nursing Sciences, (2011), Faculty of Nursing, Benha University, Egypt, (2) Assistant

Professor of Nursing Administration, Faculty of Nursing, Cairo University, Egypt and (3) Assistant Professor of Nursing Administration, Faculty of Nursing, Benha University, Egypt

\begin{abstract}
Background: Six sigma is an approach of quality management, which is intended to improve the healthcare services, and processes by continuously reducing defects due to excessive process variation in health care. Aim of study: Was to assess nursing staff readiness regard utilization of six sigma of quality management. Design: A descriptive correlational design was used. Setting: The study was conducted in critical care unit at Banha University Hospital. Subjects: A Convenient sample consisted of 266 of nursing staff divided into (236 staff nurses and 30 head nurses). Tools: Two tools were used: 1- Six sigma knowledge questionnaire and 2-Six sigma readiness questionnaires. Results: The highest percent of nursing staff had fair knowledge level regard utilization of six sigma of quality management. Also, this result showed that the majority of nursing staff had low readiness level regarding utilization of six sigma of quality management. Conclusion: There were no statistically significant relation between nursing staff knowledge and their readiness toward using of six sigma of quality management. Recommendation: Hospital administration should provide training programs to increase nursing staff awareness of six sigma and their readiness to apply six sigma in their work place.
\end{abstract}

Key words: Nursing staff -Quality management-Readiness-Six sigma

\section{Introduction}

Quality Management (QM) is the ongoing process of identifying and minimizing or removing production defects, streamlining supply chain operations, improving service, and ensuring that staff are trained to pace. Full quality control seeks to keep responsible for the overall quality of the finished product or service to all parties involved in the manufacturing process. QM is a holistic approach to optimal management of the organizations. The method focuses on enhancing the quality of process in hospital by continually improving the internal operations. When part of quality management process, the specifications set will represent both internal expectations and any technical standards currently in place (Yosep et al, 2018).

Six sigma is a multi-dimensional structured approach for improving processes, lowering defects, reducing process variability, reducing costs, increasing patient satisfaction and increased profits. Six sigma's aim to eliminate waste and inefficiency, thereby increasing patient satisfaction by delivering what the patient is expecting. Six sigma follows a structured methodology, and has defined roles for the participants. Six sigma is a data driven methodology, and requires accurate data collection for the processes being analyzed (Cheng, 2018).

Six sigma is an integrated quality program designed to enhance customer satisfaction and establish a constant change culture applying manageable solutions and 
innovative practices within the organization. Moreover, Six Sigma methodology encompasses a disciplined, knowledge-based approach due to the fact that it provides ongoing training of Six Sigma best practices and principles (Czajkowska \& StasiakBetlejewska, 2015).

Six Sigma comes from the disciplinary approach. The approach used is DMAIC (Define, Measure, Analyze, Improve, and Control) stages. The DMAIC process provides a workflow that links the various stages of six sigma. The knowledge of Six Sigma has become a revolution in the health care, and some hospitals now use the six sigma methodology to improve their quality of care (Pandi, 2016).

Six Sigma is highly measurement and data driven. Data has to be gathered to determine the baseline performance of a process in order to validate that an improvement has been made. Decisions are made on statistics and facts, rather than instinct or past history. Six Sigma projects can be led by Black Belts or Green Belts. ninjas (experts) who are trained for quality problem solving. The Master Black Belt ninjas usually serve as advisors to the project leaders while local champions promote six sigma in their organizations. All of these roles require extensive training to become familiar with the tools of Six Sigma (Patri, 2017).

Six Sigma needs top management and leaders that guide performance at every level of the organization. Six Sigma does not only help in improving the quality of the system, but it also changes the culture of the organization. In preparing to implement Six Sigma, measurements based on performance are crucial in ensuring that an organization is effective in achieving established goals and sustaining the achieved results (Pande \& Holpp, 2012).
The nurses who are trained in six sigma quality policy are capable of identifying weak areas or bottlenecks that slow down the process. Thus, Six sigma is valuable because the continuous improvement environment gives everyone an opportunity to improve traditional processes and develop new skills through accurate efficiency and effectiveness. Six sigma is predicted to sustain its dominance over the existing quality improvement techniques, since it is flexible and can be modified to meet the requirements (Choi et al, 2013).

\section{Significance of the study:}

The health care organization is the place where defects and mistakes cannot tolerate. A simple mistake can cost human life so defects or mistakes must eliminate in health care processes. Using six sigma approach is the best option in health care environment for dealing with a critical patient. Implementation of six sigma approach can be reduction in several aspects of health care such as patient waiting time in emergency departments, delinquent medical records, diagnostic result, turnaround times , account receivable days, patients' length of stay, and reduce medication errors (Selim et al, 2014).

In Banha university hospital, there are many studies conducted to identify medical errors and to determine the risk factors and consequences of these errors. The result can included that the errors were detected by follow-up of neonates and review of reports including nursing follow up sheets, resident progression notes and investigation reports. They detected 3819 errors that affected $97 \%$ of neonates. Also they found the errors included 403 medication errors $(10.55 \%$ of total errors), 652 errors in daily routine procedures $(17.07 \%), 1042$ errors in invasive procedures $(27.28 \%), 68$ errors in nutrition (1.78\%), 63 equipment errors (1.64\%), 260 
administration errors (6.8\%), 656 staffing errors (17.18\%), 107 environmental errors (2.8\%), 448 infection control errors $(11.73 \%)$ and 120 nosocomial infection errors (3.14\%) (Nabiha et al., 2012). The investigator observes many medication errors in daily routine procedures and un commitment infection control measures that threat patient safety in Banha university hospital. Thus the current study seeks to assess the nursing staff readiness regard utilization of six sigma in critical care units.

\section{Aim of the study}

The study aimed to assess nursing staff readiness regard utilization of six sigma in critical care units.

\section{Research questions:}

1-What is nursing staff knowledge level regard six sigma?

2- What is nursing staff readiness level regard six sigma?

3- What is the relationship between nursing staff knowledge and their readiness regard six sigma?

\section{Subjects and Methods}

\section{Research Design:}

A descriptive correlational design was used to achieve the aim of the present study. Setting:

The current study was conducted at Benha University Hospital (free services hospital) in the following critical care units (Catherization care unit(12 beds), Intensive care units( 22 beds), Cardiac care unit( 8 beds), Chest care unit( 6 beds), Cardiac and Chest care unit(5 beds), Pediatrics care unit(12beds), Intermediate care unit( 8 beds), Hepatic care unit(4 beds), psychiatric care unit( 6 beds) and Emergency care unit ( 8 beds).

Total bed capacity at Banha University Hospital is 880 . The hospital composed of three separated buildings; medical building (478beds), surgical building
(384 beds), ophthalmology building (18 beds). Total numbers of beds at CCUs (91beds).

\section{Subjects:}

Convenient sample of 266 nursing staff (236 nurses and 30 head nurses), who are working at the pervious mentioned setting, accept to participate in the study with experience above three years. The nursing staff was distributed as following:-

\begin{tabular}{|l|c|c|}
\hline Department & $\begin{array}{c}\text { Staff } \\
\text { nurses }\end{array}$ & $\begin{array}{c}\text { Head nurses/ } \\
\text { Assistant }\end{array}$ \\
\hline $\begin{array}{l}\text { Catherization } \\
\text { care unit }\end{array}$ & 23 & 3 \\
$\begin{array}{l}\text { Intensive care } \\
\text { units }\end{array}$ & 75 & 3 \\
\hline $\begin{array}{l}\text { Cardiac care } \\
\text { unit }\end{array}$ & 21 & 3 \\
\hline $\begin{array}{l}\text { Chest care unit } \\
\text { Cardiac and } \\
\text { Chest care unit }\end{array}$ & 15 & 3 \\
\hline $\begin{array}{l}\text { Pediatrics care } \\
\text { unit }\end{array}$ & 33 & 3 \\
\hline $\begin{array}{l}\text { Intermediate } \\
\text { care unit }\end{array}$ & 12 & 3 \\
\hline $\begin{array}{l}\text { Hepatic care unit } \\
\text { psychiatric care } \\
\text { unit }\end{array}$ & 9 & 3 \\
\hline $\begin{array}{l}\text { Emergency care } \\
\text { unit }\end{array}$ & 25 & 3 \\
\hline \begin{tabular}{l} 
Total \\
\hline
\end{tabular} & $\mathbf{2 3 6}$ & $\mathbf{3 0}$ \\
\hline
\end{tabular}

Tools of data collection:

Data of present study was collected by using two tools namely;

Tool I: Six sigma knowledge questionnaires:

It was developed by investigator based on literature review (CagnazzoL\&Taticchi 2010; Suhaiza\& Sivabalan 2011; Chodvadia \&Hirpara 2013; Bisgaard 2014) to assess nursing staff knowledge regard utilization of six sigma of quality management. It consists of two parts:-

Part (1): Personal characteristics data: Included personal data about nursing staff 
(age, gender, marital status, job, qualification, years of experiences and training course about quality).

Part (2): Six sigma knowledge questionnaire: It consisted of 32 questions in the form of true or false, multiple choice and match questions covering the following items: concept of Six Sigma, importance, purpose, principles, characteristics steps of applying Six Sigma in nursing care, team of six sigma, and process of six sigma disturbed as following:

\begin{tabular}{|l|c|c|l|}
\hline Items & $\begin{array}{l}\text { True\& } \\
\text { False }\end{array}$ & $\begin{array}{l}\text { Multipl } \\
\text { e choice }\end{array}$ & $\begin{array}{l}\text { Matc } \\
\text { h }\end{array}$ \\
\hline $\begin{array}{l}\text { Concept of six } \\
\text { sigma }\end{array}$ & 3 & 2 & ------ \\
\hline $\begin{array}{l}\text { Importance of } \\
\text { six sigma }\end{array}$ & 2 & 3 & ------ \\
\hline $\begin{array}{l}\text { Purpose of six } \\
\text { sigma }\end{array}$ & 2 & 2 & ------ \\
\hline $\begin{array}{l}\text { Principles of } \\
\text { six sigma }\end{array}$ & 1 & 2 & ------ \\
\hline $\begin{array}{l}\text { Characteristic } \\
\text { s of six sigma }\end{array}$ & 3 & 1 & ------- \\
\hline $\begin{array}{l}\text { Steps of } \\
\text { applying six } \\
\text { sigma }\end{array}$ & 1 & 1 & ------ \\
\hline $\begin{array}{l}\text { Team of six } \\
\text { sigma }\end{array}$ & 4 & --------- & ------- \\
\hline $\begin{array}{l}\text { Process of six } \\
\text { sigma }\end{array}$ & --------- & ------- & 5 \\
\hline Total & 16 & 11 & 5 \\
\hline
\end{tabular}

Scoring system:

The scoring system for nursing staff knowledge was calculated as following; (1 score) for correct answer and (0) for incorrect and don't know answer. The score of items was summed up and the total divided by the number of the items, giving a mean score for the part. These scores were converted into a percent score.
The total knowledge score (32degrees) and it was considered good knowledge level if the score of the total knowledge $\geq 75 \%$ ( $\geq 24$ degrees), while considered fair if it equals $60-<75 \%$ from $19-<24$ degrees). While consider poor knowledge level if it is $>60 \%$ ( $<19$ degrees).

Tool II: Six sigma readiness questionnaire: it developed by investigator based on literature review (Swink \& Jacobs 2012, Ofili 2014, Biswas\& Chowdhury 2016) to assess nursing staff readiness toward utilization Six sigma of quality management. It consisted of 38 items divided into 5 dimensions distributed as following, Six sigma readiness(12 items) divided into 2 subcategory; optimism (7 items) and innovativeness(5 items), benefits of using six sigma(9 items), support toward using Six sigma(5 items), motivation toward using six sigma(6 items) and attitude toward six sigma(6 items).

\section{Scoring system:}

Nursing staff responses were scored on a five point Likert Scale ranged from (1) rarely to (5) always. The total score was calculated and converted in to percentages. . The total readiness score was 190 degrees The readiness of six sigma consider high if the total score was more than $75 \%(\geq 142$ degrees), while readiness level considered moderate if the total score was more than 60$<75 \%$ (from 114-< 142 degrees), while low readiness level if the total score was less than $60 \%$ ( < 114 degrees).

\section{Tool validity:}

Face and content of study tools were validated by group of jury consisted of five experts from different faculties of nursing (three assistant Professors from Cairo University and two assistant Professors from Benha University). The modifications were done based on jury opinions such as ( omitted the items that gives the same meaning and 
modifying some words to give the right meaning for the item which did not understood clearly).

\section{Reliability of tools:}

It was measured by using Cronbach's Alpha test. The Cronbach's Alpha test of knowledge of nursing staff regarding Six Sigma utilization in nursing care was 0.813 and the cronbach's Alpha test of nursing staff readiness toward Six Sigma utilization in nursing was 0.986 .

\section{Pilot study:}

A pilot study was carried out in June 2019 to ascertain to clarify and applicability of study tools. Pilot study representing $10 \%$ of total sample (23 nursing staff). It has also served in estimating the time needed for filling the tools. It ranged from 15-20 minutes for six sigma knowledge questionnaire and 15:20 minutes for six sigma readiness questionnaire. No modification was needed and pilot study included in the actual study sample.

\section{Field work:}

Data collection took two months from beginning of July 2019 to the end of August 2019. The investigator met nursing staff and explained the aim and the nature of the study and the methods of filling questionnaire. The investigator distributed the questionnaire sheets to the participants to fill it in work times which determined in advance with head nurse of each unit according to the type of work. Data was collected in three days/week in morning shift in the presence of the investigator to clarify any ambiguity. The average number of sheets filled per week was ranged 30 questionnaires per week).

\section{Ethical Considerations:}

Before conducting the study, explanation of the nature and aim of the study have been explained to nursing staff included in the study. All subjects were informed that participation in the study is voluntary and informed consent was obtained from each participant in the study. Confidentiality of data obtained was protected by the allocation of a code number to the questionnaire sheets. Subjects were informed that the content of the study tools will be used for the research purpose only. Participants' right to withdraw from the study at any time was ascertained.

\section{Statistical analysis:}

Data were verified prior to computerized entry. The statistical package for social Sciences (SPSS version 20) was used. Descriptive statistics were applied in the form of mean and standard deviation for quantitative variables and frequency and percentages for qualitative variables. Qualitative categorical variables were compared using chi-square test. The statistical significance was considered when $\mathrm{p}$ - value $<0.05$. A highly statistically significance was considered when $\mathrm{p}$ - value $<0.001$ and considered not significance when $\mathrm{p}$ value $>0.05$.

\section{Results:}

Table (1): Show that, more than half of nursing staff (68\%) were aged from 20-30 years old. The majority of nursing staff ( 97 . $4 \%, 86.8 \%$ ) of them were female and married. Regarding the job more than three quarters $(88.7 \%)$ of nursing staff were work as staff nurses. As regarding to qualification more than one third $(38.7 \%)$ of them were had diploma in nursing. While less than half $(47.7 \%)$ of them had experience ranged from (6-10 years). The majority of nursing staff (71.8\%) didn't have training course about quality management.

Table (2): Clarifies that, the highest mean percent of nursing staff $(91 \%)$ was related of purpose of six sigma follow by concept of six sigma and principles of six sigma $(90.8 \%, 90 \%)$ respectively, while the 
lowest mean percent $(54.5 \%)$ was related to six sigma team.

Table (3): Clarifies that, the highest mean percent was $(50.6 \%)$ of nursing staff readiness of six sigma dimensions was related to optimism to follow by motivation toward using six sigma $(47.3 \%)$, while the lowest mean percent $(23.18 \%)$ of nursing staff readiness of six sigma of quality management dimensions were related to benefit of using six sigma.

Table (4): Indicates that there was highly statistical significant relation between nursing staff knowledge regard six sigma and their job, qualification and attending training course about quality management.

Table (5): Indicates that there was statistical significant relation between nursing staff readiness regard six sigma and nursing qualification.
Table (6): Demonstrate that, there was no statistical significant relation between knowledge and readiness about six sigma of quality management.

Figure (1): Indicates that the highest percent of nursing staff $(38.2 \%)$ had fair knowledge level regard utilization of six sigma of quality management, less than one quarter $(27.5 \%)$ of nursing staff had good knowledge regard utilization of six sigma of quality management and more than one quarter $(34.3 \%)$ of nursing staff had poor knowledge regard utilization of six sigma of quality management among nursing staff.

Figure (2): Clarifies that, less than one quarter $(19.5 \%)$ had high readiness level regard six sigma of quality management and (60.2\%) of nursing staff had low readiness level regard six sigma of quality management.

Table (1): Frequency distribution of nursing staff regarding personal characteristics $\quad(n=266)$

\begin{tabular}{|c|c|c|c|}
\hline \multicolumn{2}{|c|}{ Personal characteristics } & Frequency & $\%$ \\
\hline \multirow{3}{*}{ Age in years } & Less than 20 & 15 & 5.6 \\
\hline & $20-30$ & 181 & 68.0 \\
\hline & $>30$ & 70 & 26.3 \\
\hline \multirow{2}{*}{ Gender } & Male & 7 & 2.6 \\
\hline & Female & 259 & 97.4 \\
\hline \multirow{2}{*}{ Marital status } & Single & 35 & 13.2 \\
\hline & Married & 231 & 86.8 \\
\hline \multirow{3}{*}{ Job } & Nurse & 201 & 75.6 \\
\hline & Head nurse & 32 & 12.0 \\
\hline & Supervisor nurse & 33 & 12.4 \\
\hline \multirow{4}{*}{ Qualification } & Diploma in nursing & 103 & 38.7 \\
\hline & Technical nursing institute & 72 & 27.1 \\
\hline & Bachelor of nursing & 77 & 28.9 \\
\hline & Master degree & 14 & 5.3 \\
\hline \multirow{4}{*}{ Years of experiences } & Less than 5 years & 65 & 24.4 \\
\hline & $6-10$ & 127 & 47.7 \\
\hline & $11-15$ & 68 & 25.6 \\
\hline & More than 15 years & 6 & 2.3 \\
\hline \multirow{2}{*}{$\begin{array}{l}\text { Training course } \\
\text { about quality }\end{array}$} & Yes & 75 & 28.2 \\
\hline & No & 191 & 71.8 \\
\hline
\end{tabular}


Table (2): Ranking, mean and standard deviation of nursing staff knowledge regard six sigma of quality management $(n=266)$

\begin{tabular}{|l|c|c|c|c|}
\hline \multicolumn{1}{|c|}{ Six sigma } & Max score & Mean \pm SD & Mean\% & Rank \\
\hline Concept of six sigma & 5 & $4.54 \pm 1.48$ & $90.8 \%$ & 2 \\
\hline Importance of six sigma & 5 & $4.24 \pm 1.71$ & $84.8 \%$ & 4 \\
\hline Purpose of six sigma & 4 & $3.64 \pm 1.20$ & $91 \%$ & 1 \\
\hline Principle of six sigma & 3 & $2.70 \pm 1.10$ & $90 \%$ & 3 \\
\hline Characteristics of six sigma & 4 & $2.90 \pm 1.25$ & $72.5 \%$ & 5 \\
\hline Steps of applying six sigma & 2 & $1.40 \pm 0.76$ & $70 \%$ & 6 \\
\hline Six sigma Team & 4 & $2.18 \pm 0.94$ & $54.5 \%$ & 8 \\
\hline Process of six sigma & 5 & $3.2 \pm 1.15$ & $64 \%$ & 7 \\
\hline Total knowledge & 32 & $23.48 \pm 4.61$ & $73.37 .7 \%$ & \\
\hline
\end{tabular}

Table (3): Ranking, mean and standard deviation of nursing staff readiness of six sigma of quality management dimensions

\begin{tabular}{|l|c|rc|c|c|}
\hline & Max score & \multicolumn{2}{|l|}{$\begin{array}{l}\text { Mean } \\
\text { Deviation }\end{array}$} & $\begin{array}{l}\text { Mean } \\
\text { percent }\end{array}$ & Ranking \\
\hline Optimism & 35 & $17.73 \quad \pm 4.58$ & $50.6 \%$ & 1 \\
\hline Innovation & 25 & $11.75 \quad \pm 4.02$ & $47 \%$ & 3 \\
\hline $\begin{array}{l}\text { Benefit of using } \\
\text { six sigma }\end{array}$ & 45 & $19.41 \quad \pm 5.88$ & $23.18 \%$ & 6 \\
\hline $\begin{array}{l}\text { Support toward } \\
\text { using six sigma }\end{array}$ & 25 & $9.75 \pm 4.19$ & $39 \%$ & 5 \\
\hline $\begin{array}{l}\text { Motivation toward } \\
\text { using six sigma }\end{array}$ & 30 & $14.21 \quad \pm 3.47$ & $47.3 \%$ & 2 \\
\hline $\begin{array}{l}\text { Attitude toward } \\
\text { using six sigma }\end{array}$ & 30 & 13.11 & \pm 3.52 & $43.7 \%$ & 4 \\
\hline total & 190 & 85.99 & \pm 14.89 & $45.25 \%$ & \\
\hline
\end{tabular}


Table (4): Relation between nursing staff knowledge regard six sigma and their personal characteristics

\begin{tabular}{|c|c|c|c|c|c|c|c|c|}
\hline \multirow{2}{*}{$\begin{array}{c}\text { Personal } \\
\text { characteristics }\end{array}$} & \multicolumn{2}{|c|}{ Poor $(n=92)$} & \multicolumn{2}{|c|}{ Fair(n= 98) } & \multicolumn{2}{|c|}{ Good $(n=76)$} & \multirow[t]{2}{*}{$\mathbf{X}^{2}$} & \multirow[t]{2}{*}{ p-value } \\
\hline & no & $\%$ & no & $\%$ & no & $\%$ & & \\
\hline \multicolumn{9}{|l|}{ Age in years } \\
\hline Less than 20 & 5 & 5.4 & 7 & 7.1 & 3 & 3.9 & \multirow[t]{3}{*}{4.905} & \multirow{3}{*}{$\begin{array}{l}0.297 \\
\text { s }\end{array}$} \\
\hline $20-30$ & 68 & 73.9 & 59 & 60.2 & 54 & 71.1 & & \\
\hline$>30$ & 19 & 20.7 & 32 & 32.7 & 19 & 25.0 & & \\
\hline \multicolumn{9}{|l|}{ Gender } \\
\hline Male & 2 & 2.2 & 4 & 4.1 & 1 & 1.3 & \multirow[t]{2}{*}{1.393} & \multirow[t]{2}{*}{0.498} \\
\hline Female & 90 & 97.8 & 94 & 95.9 & 75 & 98.7 & & \\
\hline \multicolumn{9}{|l|}{ Marital status } \\
\hline Single & 7 & 7.6 & 14 & 14.3 & 14 & 18.4 & \multirow[t]{2}{*}{4.431} & \multirow[t]{2}{*}{0.109} \\
\hline Married & 85 & 92.4 & 84 & 85.7 & 62 & 81.6 & & \\
\hline \multicolumn{9}{|l|}{ Job } \\
\hline Nurse & 89 & 96.7 & 77 & 78.6 & 68 & 89.5 & \multirow[t]{2}{*}{29.64} & \multirow[t]{2}{*}{$.000 * *$} \\
\hline Head nurse & 3 & 3.3 & 21 & 21.4 & 8 & 10.5 & & \\
\hline \multicolumn{9}{|l|}{ Qualification } \\
\hline Diploma in nursing & 53 & 57.6 & 45 & 45.9 & 5 & 6.6 & \multirow[t]{4}{*}{58.79} & \multirow[t]{4}{*}{$.000 * *$} \\
\hline Technical institute & 23 & 25.0 & 17 & 17.3 & 32 & 42.1 & & \\
\hline Bachelor of nursing & 16 & 17.4 & 27 & 27.6 & 34 & 44.7 & & \\
\hline Master degree & 0 & 0.0 & 9 & 9.2 & 5 & 6.6 & & \\
\hline \multicolumn{9}{|l|}{ Years of experience } \\
\hline$<5$ years & 22 & 23.9 & 19 & 19.4 & 24 & 31.6 & \multirow[t]{4}{*}{14.24} & \multirow[t]{4}{*}{$.027 *$} \\
\hline $6-10$ & 36 & 39.1 & 53 & 54.1 & 38 & 50.0 & & \\
\hline $11-15$ & 29 & 31.5 & 25 & 25.5 & 14 & 18.4 & & \\
\hline$>15$ years & 5 & 5.4 & 1 & 1.0 & 0 & 0.0 & & \\
\hline \multicolumn{9}{|c|}{ Training course about quality management } \\
\hline Yes & 13 & 14.1 & 27 & 27.6 & 35 & 46.1 & \multirow[t]{2}{*}{20.98} & \multirow[t]{2}{*}{$.000 * *$} \\
\hline No & 79 & 85.9 & 71 & 72.4 & 41 & 53.9 & & \\
\hline
\end{tabular}


Nursing Staff Readiness regarding Utilization of Six Sigma of Quality Management in Critical Care Units

Table (5): Relation between nursing staff readiness regard six sigma of quality management and their personal characteristics $(n=266)$

\begin{tabular}{|c|c|c|c|c|c|c|c|c|}
\hline & \multicolumn{2}{|c|}{ Low $(n=160)$} & \multicolumn{2}{|c|}{ Moderate $(n=54)$} & \multicolumn{2}{|c|}{ High $(n=52)$} & \multirow{2}{*}{$\mathbf{X}^{2}$} & \multirow{2}{*}{$\begin{array}{l}\text { p- } \\
\text { value }\end{array}$} \\
\hline & no & $\%$ & no & $\%$ & no & $\%$ & & \\
\hline \multicolumn{9}{|l|}{ Age in years } \\
\hline Less than 20 & 10 & 6.3 & 2 & 3.7 & 3 & 5.8 & \multirow{3}{*}{1.749} & \multirow{3}{*}{0.782} \\
\hline $20-30$ & 112 & 70.0 & 36 & 66.7 & 33 & 63.5 & & \\
\hline$>30$ & 38 & 23.8 & 16 & 29.6 & 16 & 30.8 & & \\
\hline \multicolumn{9}{|l|}{ Gender } \\
\hline Male & 2 & 1.3 & 3 & 5.6 & 2 & 3.8 & \multirow[t]{2}{*}{3.293} & \multirow[t]{2}{*}{0.193} \\
\hline Female & 158 & 98.8 & 51 & 94.4 & 50 & 96.2 & & \\
\hline \multicolumn{9}{|l|}{ Marital status } \\
\hline Single & 25 & 15.6 & 3 & 5.6 & 7 & 13.5 & \multirow{2}{*}{3.588} & \multirow{2}{*}{0.166} \\
\hline Married & 135 & 84.4 & 51 & 94.4 & 45 & 86.5 & & \\
\hline \multicolumn{9}{|l|}{ Job } \\
\hline Nurse & 146 & 91.2 & 45 & 83.3 & 43 & 82.7 & \multirow[t]{2}{*}{5.735} & \multirow[t]{2}{*}{0.22} \\
\hline Head nurse & 14 & 8.8 & 9 & 16.7 & 9 & 17.3 & & \\
\hline \multicolumn{9}{|c|}{ Nursing qualification } \\
\hline $\begin{array}{l}\text { Diploma in } \\
\text { nursing }\end{array}$ & 59 & 36.9 & 22 & 40.7 & 22 & 42.3 & \multirow{4}{*}{12.315} & \multirow{4}{*}{0.055} \\
\hline $\begin{array}{l}\text { Technical } \\
\text { institute }\end{array}$ & 47 & 29.4 & 12 & 22.2 & 13 & 25.0 & & \\
\hline $\begin{array}{l}\text { Bachelor of } \\
\text { nursing }\end{array}$ & 50 & 31.3 & 17 & 31.5 & 10 & 19.2 & & \\
\hline Master degree & 4 & 2.5 & 3 & 5.6 & 7 & 13.5 & & \\
\hline \multicolumn{9}{|c|}{ Years of experience } \\
\hline$<5$ years & 41 & 25.6 & 14 & 25.9 & 10 & 19.2 & \multirow{4}{*}{10.604} & \multirow{4}{*}{0.101} \\
\hline $6-10$ & 74 & 46.3 & 26 & 48.1 & 27 & 51.9 & & \\
\hline $11-15$ & 43 & 26.9 & 10 & 18.5 & 15 & 28.8 & & \\
\hline$>15$ years & 2 & 1.3 & 4 & 7.4 & 0 & 0.0 & & \\
\hline \multicolumn{9}{|c|}{ Training course about quality management } \\
\hline Yes & 52 & 32.5 & 11 & 20.4 & 12 & 23.1 & \multirow[t]{2}{*}{3.77} & \multirow[t]{2}{*}{0.152} \\
\hline No & 108 & 67.5 & 43 & 79.6 & 40 & 76.9 & & \\
\hline
\end{tabular}

Table (6): Relation between nursing staff knowledge and readiness regard six sigma of quality management

\begin{tabular}{|c|c|c|c|c|c|c|c|}
\hline \multirow{2}{*}{ knowledge } & \multicolumn{2}{|c|}{ Low $(n=160)$} & \multicolumn{2}{|c|}{ Moderate $(n=54)$} & \multicolumn{2}{|c|}{ High $(n=52)$} & $\begin{array}{c}\mathbf{X}^{2} \\
\text { p-value }\end{array}$ \\
\hline & no & $\%$ & no & $\%$ & no & $\%$ & \multirow{4}{*}{$\begin{array}{l}3.182 \\
0.528\end{array}$} \\
\hline Poor $(n=92)$ & 59 & 64.1 & 53 & 54.1 & 48 & 63.2 & \\
\hline $\begin{array}{l}\text { Fair } \\
(n=98)\end{array}$ & 17 & 18.5 & 21 & 21.4 & 16 & 21.1 & \\
\hline $\operatorname{Good}(n=76)$ & 16 & 17.4 & 24 & 24.5 & 12 & 15.7 & \\
\hline
\end{tabular}




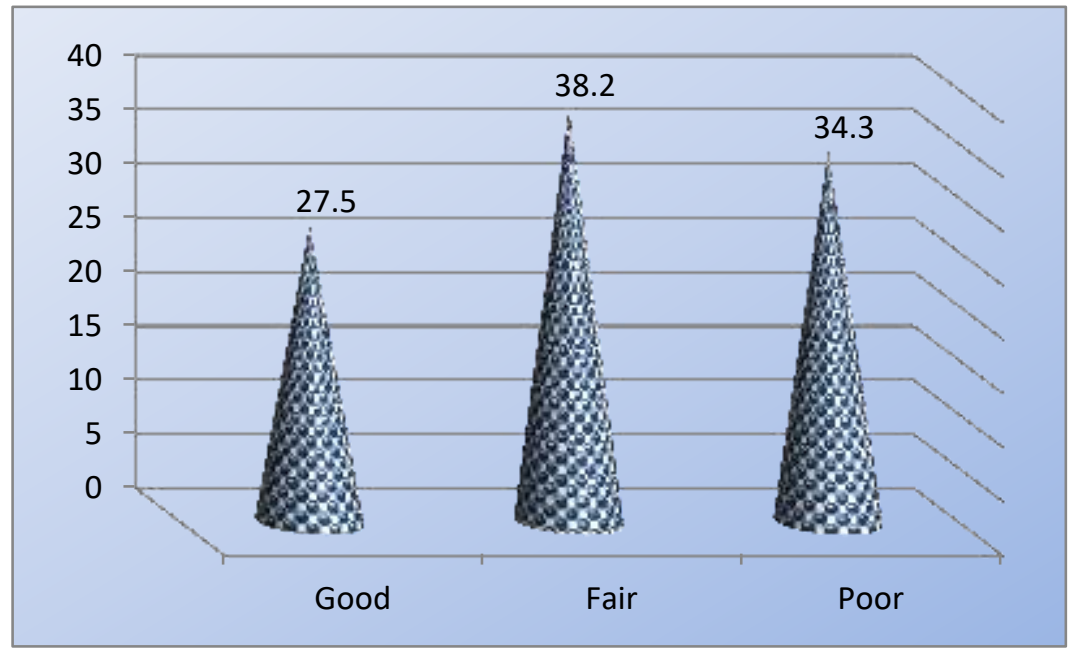

Figure (1): Nursing staff total knowledge level of six sigma of quality management

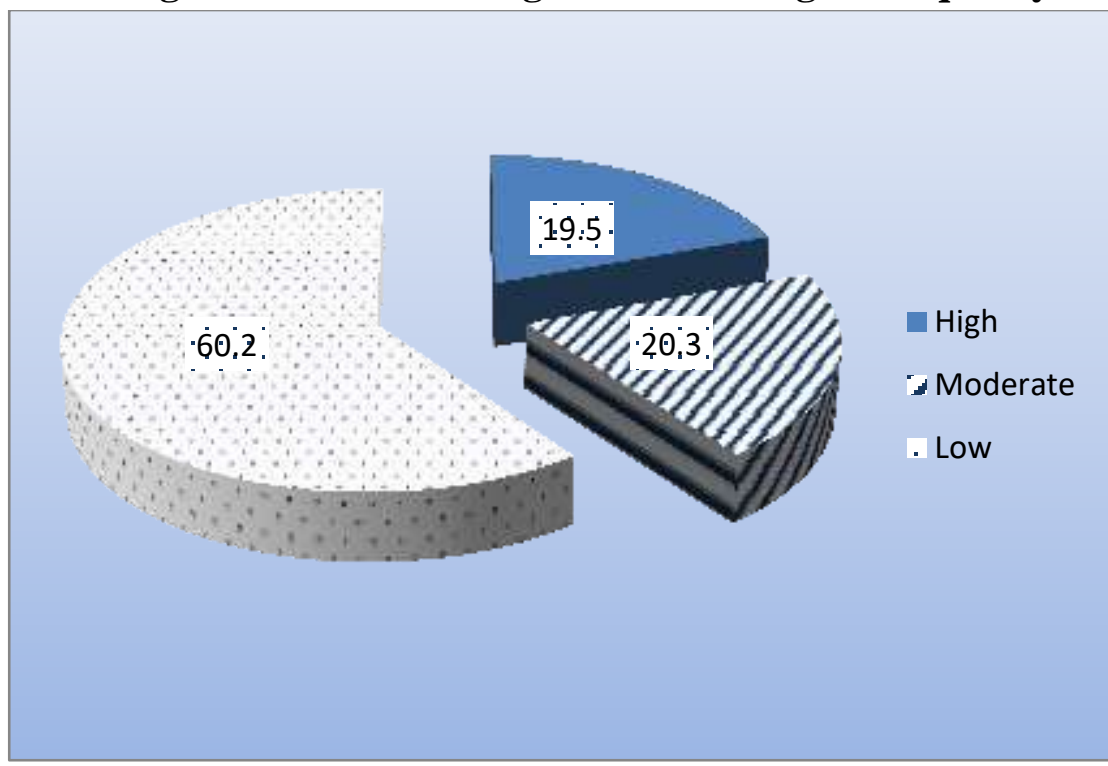

Figure (2): Nursing staff readiness levels regard six sigma of quality management

\section{Discussion:}

Six sigma is an important advance in quality management and process improvement in the last two decades. Six sigma has gained wide popularity in various types of organizations since the 1990. Six sigma is a set of tools and techniques for problem solving or process improvement .It can help hospital to achieve significant performance improvement. It provides continuous and sustain opportunities for the advancement of hospitals ,increase the quality of nursing care and gives a high degree of confidence and increase patient satisfaction improvement, and sales revenue growth ( Qamar et al, 2020).

This study aimed at assess nursing staff readiness regard utilization of six sigma of quality management.

Concerning ranking, mean and standard deviation of nursing staff knowledge regard six sigma of quality management, the current study clarifies that, the highest mean percent of nursing staff knowledge of six sigma dimensions was related to purpose of six sigma. This may be due to six sigma is used for optimizing and improving the existing nursing processes. It is an effective 
method of controlled change management, while the lowest mean percent of nursing staff knowledge of six sigma related to six sigma team. That may be due to six sigma team is not applicable in Benha university hospital and nursing staff not aware of roles of six sigma in work place. Six sigma team refines the problem statement, goals and identifies the factors which are critical to quality this ensure the work goals and priorities. The result of this study was agreed with Jirasukprasert et al., (2012) who conducted a study about "A case study of defects reduction in a rubber gloves manufacturing process by applying Six Sigma principles and DMAIC problem solving methodology". They showed that the majority of employees reported the purpose of six sigma reducing errors in their manufacturing process in company. The result of this study was disagreed with Sujova et al., (2016) who conducted a study about sustainable process performance by application of six sigma concepts in the Slovak republic. They showed that the highest percent of the subjects reported that important role of six sigma in work place.

Concerning ranking, mean and standard deviation of nursing staff regarding six sigma dimensions, the present study showed that the highest mean percent was related to optimism followed by motivation, while the lowest mean percent was related to benefits of using six sigma. This may be due to optimism that nursing staff can get more information about six sigma and can able to implement six sigma in nursing care effectively. This result of this study was agreed with Verver et al., (2018) who conducted a study about "Lean six sigma in healthcare to illustrate how principles of Lean". They revealed that the highest percent was of medical staff readiness of six sigma dimensions was related to commitment of applying six sigma in health care.In the other hand this result disagree with Park, et al (2017) who conducted a study about "Alignment between internal and external governance and its effects on distinctive firm performance". They showed that the majority of employees reported that mechanistic organization structure for six sigma implementation may stifle employee motivation for creativity and innovation.

Concerning relation between nursing staff knowledge regard six sigma and their personal characteristics. The study indicated that there was highly statistical significant relation between nursing staff knowledge regard six sigma and their job and nursing qualification. Also there no statistical significant relation between knowledge and years of experiences. This may be due to the higher education al qualification, the better acquire knowledge of health care quality because the educational courses at nursing diploma and bachelor levels have some quality content.This result of this study was disagreed with Sujova, et al. (2016) who conducted that there was highly statistical significant relation between nursing staff knowledge regard six sigma and qualification. Also there was highly statistical significant relation between knowledge and years of experiences.

Regarding relation between nursing staff readiness regard six sigma and their personal characteristics, the current study illustrated that there was statistical relationship between nursing staff readiness regard using six sigma of quality management and nursing qualification. This may be due to the higher education al qualification, the better acquire knowledge of health care quality and nursing staff can be ready to implement six sigma.This result of present study was disagreed with Bhaskar, ( 2020) 
who showed that there was statistical relationship between nursing staff readiness regard six sigma and attained quality courses.

Regarding relation between nursing staff knowledge and their readiness regard utilization of six sigma of quality management, the current study illustrated that there was no statistical relationship between nursing staff knowledge and their readiness regard utilization of six sigma. This may be due to quality improvement in healthcare monitors, assesses and improves the standards of quality healthcare, continuous up gradation in healthcare activities can pull out healthcare organizations from inefficient traditional concepts and utilize technology/tools to perform efficiently and hence generate better quality results.

This result of this study was disagreed with Ialongo \& Bernardini (2018) who conduct study about" an introduction to the short-term and long term Six Sigma quality and its importance in laboratory medicine for the management of extra-analytical processes". They showed that there was significant relation between knowledge and important of change management regard lean six sigma system, this result in same line with Mohamed, (2020) who conducted a study about "Nursing personal readiness toward using lean management in Benha and Shebein Elkom hospitals" who revealed that there was highly significant positive correlation between total knowledge and readiness items regard lean management among head nurses at two hospitals.

Concerning nursing staff knowledge regard utilization of six sigma of quality management levels, the current study showed that the highest percent of nursing staff had fair knowledge level regard utilization of six sigma of quality management, less than one quarter of nursing staff had good knowledge regard utilization of six sigma of quality management and more than one quarter of nursing staff had poor knowledge regard utilization of six sigma of quality management among nursing staff. This is may be due to effective implementation of Six Sigma was based on needed identification of quality enhancement practices by means of determining ineffectiveness of a traditional quality management mechanism. So that Banha University Hospital had recent quality unit (2014) to implement its activities through conduct workshops to train nursing staff about quality recognition, quality control and quality improvement. The result of this study was agreed with Muhamud\& Hassan, (2012) who conducted study about "The prevalence of six sigma trends in construction industry in pakistan". Who, showed that more than two thirds of employees in the organization didn't have adequate knowledge regard six sigma in work place. The result of this study was disagreed with Ramayah \& Zailani ,(2015) who conducted study about" six sigma and organizational performance in Malysia". They showed that the majority of employees had good knowledge level about lean six sigma.

Regarding nursing staff readiness levels of six sigma of quality management, the current study illustrated that less than one quarter had high readiness regard six sigma of quality management . This may be due to hospital administration encourage nursing staff to implement components of quality in nursing process but nursing staff not ready to apply six sigma in their work place. This result of this study was agreed with Liberatore, ( 2014) who conducted study about "comprehensive review and assessment of the extant six sigma healthcare literature", he showed that more than half of medical staff had high readiness regard application of six sigma in hospital. The result of this study was disagreed with Sreedharan and Sunder, 
(2018) who conducted a study about "A novel approach to lean six sigma project management: a conceptual framework and empirical application, Production Planning \& Control. They showed that high percent of workers reported that six sigma had emphasized the importance of readiness assessment and determined their readiness for lean six sigma deployment.

\section{Conclusion}

Less than one quarter of nursing staff had good knowledge regard six sigma of quality management and more than one quarter of nursing staff had poor knowledge regard six sigma of quality management among nursing staff. The highest mean percent regard of purpose of six sigma follow by concept of six sigma, while the lowest mean percent was related to process of six sigma. More one quarter had high readiness regard utilization six sigma of quality management and more than half of nursing staff had low readiness levels regard six sigma of quality management, the highest mean percent was of nursing staff readiness of six sigma dimensions was related to optimism to follow by motivation, while the lowest mean percent of nursing staff readiness of six sigma of quality management dimensions were related to benefit of using six sigma. Also there was no statistical significant relation between knowledge and readiness about six sigma of quality management.

\section{Recommendations}

\section{Hospital administration level:}

- Hospital administration should provide training programs for nursing staff to raise their awareness about six sigma and to apply six sigma in clinical practice.

- Create common goal to implement six sigma must be established for all nursing staff to reduce variability of nursing process, and goals should be defined and given to all quality team members.

- Hospital should encourage nursing staff to apply six sigma in clinical practice

- Motivating and rewarding nursing staff when apply six sigma in clinical practice.

- Hospital should form six sigma team to training nursing staff about how to apply six sigma in nursing care.

- Adopt and initiate a quality assurance unit mission to implement six sigma and monitor its implementation.

\section{On the research level:}

- Reapplication of the current study on other hospitals to get six sigma benefits and effectiveness for quality of nursing staff performance and patient care.

- Conduct study to identify factors and barriers effect on implementing six sigma of quality management.

- Identify effect of applying six sigma on decrease of length of stay of patient in critical care units.

\section{References:}

Bhaskar, H. (2020). Lean Six Sigma in Nursing: A Comprehensive Review available @ http://dx .doi.org/10 .5772/inte chope n.89859, accessed on 15march 2021.

Bisgaard,S.(2014).Improving health care processes with six sigma . Quality Management in Health Care Journal, 16:2833.

Biswas S., \&Chowdhury B., (2016). Industrial Applications and Practices of Six Sigma-A Literature Review, International Advanced Research Journal in Science, Engineering and Technology, 3( 3): 176-179.

Cagnazzo L.,\&Taticchi ,P.(2010). Six sigma for big companiesand MEs :evidences from literature, transaction on business and economics,7(4) 
Cheng, J. (2018). Implementing Six Sigma via TQM improvement: An empirical study inTaiwan. The TQM Journal, 20(3), 182-195. Chodvadia N. M., \&Hirpara K. P., (2013). Six Sigma Methodology: How To Use ADmaic Process For Improving Quality: Review, International Journal of EngineeringResearch\& Technology, 2( 4):966-972.

Choi, B., Choi, Y., \& Shin, S. (2013). Applications of quality improvement and robust design methods to pharmaceutical research and development. International Journal of Industrial Engineering, 20 (3), 290299.

Czajkowska, A., \& Stasiak-Betlejewska, R. (2015). Quality management tools applying the strategy of logistics service quality improvement. Serbian Journal of Management, 10(2), 225-234. DOI: 10.5937/sjm 10-8095

Ialongo C, Bernardini S,( 2018). Long story short: an introduction to the short-term andlongterm Six Sigma quality and its importance in laboratory medicine for the management of extra-analytical processes. Clin Chem Lab Med.2018;56:183845.https://doi.org/10.1515/cclm-2018-0310

Jirasukprasert, P, Garza-R, Soriano $M$ and Rocha.L. (2012). "A case study of defects reduction in a rubber gloves manufacturing process by applying Six Sigma principles and DMAIC problem solving methodology", Paper presented at the Proceedings of the 2012 International Conference on Industrial Engineering and Operations Management, Istanbul, Turkey.

Liberatore, M. (2014). Six Sigma in healthcare delivery, International Journal of Health Care Quality Assurance, 28 ( 2);. 4-11. Mohamed M, (2020). Literature review about nursing personal readiness toward using lean management in Benha and Shebein Elkom hospitals.

Muhamed. M. Hassan (2012). "The prevalence of six sigma trends in the construction industry Pakistan"master thesis

Nabiha, D, Rafaie M ,and Samah, (2012). Medical errors in neonatal intensive care unit at B enha university hospital, from August 2012 to January 2013..

Ofili O , (2014). Patient satisfaction in healthcare delivery- a review of currentapproaches and methods, European Scientific Journal, September, 10 (25):25-39.

Pande, P., \& Holpp, L,(2012). Six Sigma as a total quality management tool,'South African Journal of Industrial Engineering, 13(1), 25-33.

Pandi A., Sethupathi P., and Jeyathilagar D.,(2016). “Quality sustainability in engineering educational institutions_A theoretical model," Int. J.Productiv. Qual. Manage., 18 (2): 364.

Park, J, Lee, O. Lee D and. Koo, Y (2017). Alignment between internal and external governance and its effects on distinctive firm performance: An extended resource-based view", IEEE Trans. Eng. Manage., 64, (3): 351-364.

Patri, R. and Suresh, M. (2017). "Modelling the enablers of agile performance in healthcare organization: a TISM approach", Global Journal of Flexible Systems Management, 18 (3):251-272.

Qamar A, Hall M, Chicksand D, Collinson S (2020). Quality and flexibility performance trade-offs between lean and agile manufacturing firms in the automotive industry. Prod Plan Control 31(9):723-738.

Rmayah, T. and Zailani, Z. (2015). Six Sigma and organisational performance: A knowledge creation perspective Journal of 
Productivity and Quality Management, 6 (2):180-185.

Selim.A., Noor H.A.M., Rfikul.I. (2014). Effects of lean six sigma application in health care services: A literature review. Reviews on environmental health,28( 4):189-194.

Sreedharan, V\& Sunder, M. (2018). A novel approach to lean six sigma project management: a conceptual framework and empirical application, Production Planning \& Control, 29 (11): 895-907.

Suhaiza.Z., \& Sivabalan. S., (2011). Investigation on the six sigma critical success factors. European Journal of Scientific Research,.57(1):124-132.

Sujova, A., Simanova, L. and Cinekova, K. (2016). Sustainable Process Performance by Application of Six Sigma Concepts, Available @www.mdpi.com/journal/sustainability accessed on 3 january 2021.

Swink M., \&Jacobs B,(2012). Six Sigma adoption: Operating performance impacts and contextual drivers of success, Journal of Operations Management, 30,437-453

Verver, R, Klefsjö, B., Wiklund, H., \& Edgeman, R. L. (2018). "Six Sigma seen as a methodology for total quality management". Measuring Business Excellence, 5(1), 31-35.

Yosep Hernawan, Sri Wijaya Kesuma Dewi, Musafa(2018). "Implementation of ISO 9001: Quality Management System in PT Tarumatex Bandung", Journal of Economic ate Studies (JoES) 2(1):45-60. 


\section{استعداد هيئة التمريض تجاه إستخدام ستة سيجما لإدارة الجودة فى وحدات الرعاية الحرجة}

$$
\text { انوار محمود فتحي - ايمان عبدالعليم عطاوي- فوزية فاروق كامل السيد }
$$

تعمل ستة سيجما على تحسين الجودة فى الرعاية الصحية من خلال تحليل البيانات مع الأحصائيات وتخفيض الأخطاء الطبية وتخفيض مدة أقامة المريض بالمستشفى ورفع الطاقة الأنتاجية لغرف العمليات وتعمل على زيادة رضاء المريض والعاملين فى الرعاية الصحية. لذا هدفت الدراسة إلى معرفة مدى أستعداد هيئة التمريض لأستخدام ستة سيجما فى وحدات الرعاية الحرجة فى مستشفى بنها الجامعى. وقد أجريت الدراسة الحالية فى وحدات الرعاية الحرجة فى مستثفى بنها الجامعى على عينة متاحة وعددها (T7Y) من هيئة التمريض مقسمة إلى (דr (ب مدرض/ ممرضة و • ب رئيسة وحدة). وقد أظهرت الدر اسة النتائج التالية: فكانت أعلى نسبة من العينة المشاركة من هيئة التمريض لديهم معرفة متوسطة لستة سيجما لإدارة الجودة ومعظم هيئة التمريض لديهم استعداد منخفض لاستخدام ستة سيجما لإدارة الجودة. كما اوصت الدراسة بأنه يجب على إدارة المستشفى عمل بر امج تدريبية لهيئة التمريض لزيادة و عيهم بستة سيجما وتطبيقها فى الرعاية الصحية. 